BACKGROUND: Transient hypertension (TH) and preeclampsia (PE) are believed to have different pathophysiology. However, 15-25\% of pregnant women initially diagnosed as having TH develop PE. To clarify the immuno-pathogenetical connections between the two syndromes, we studied the pattern of $T$ helper cell (Th)1/Th2 cytokine balance disturbances existing inside maternal decidua in normal pregnancy (NP) and pregnancies complicated with TH and PE.

Methods: Third-trimester decidual tissue was obtained by curettage of uterine cavity during elective caesarean sections in NP $(n=11)$, TH $(n=17)$ and PE $(n=21)$ patients. Cell suspensions were prepared by an electromechanical dispersal method and centrifugated using a standard gradient sedimentation technique. Isolated lymphocytes were placed in medium (RPMI 1640, 10\% fetal calf serum, L-glutamine, penicillin, streptomycin) and cultured for $72 \mathrm{~h}$ with or without mitogen phytohaemaglutinine (PHA). The enzyme-linked immunosorbent assay method was used for estimation of interleukin (IL)-2, IL-4, IL-6, IL-10, IL-12 and interferon- $\gamma$ (IFN $\gamma)$ in culture supernatant.

Statistical analysis: The Kruskal-Wallis and the Mann-Whitney $U$ tests were used $(p<0.05)$.

Results: Both spontaneous and PHA-stimulated secretion of Th2-type cytokines IL-6 and IL-10 was decreased in PE patients compared with TH and NP patients. The concentration of Th1-type cytokine IFN $\gamma$ was increased in patients suffering both from TH and PE.

Conclusion: On the base of decidual cytokine secretion, both PE and TH are syndromes of local Th1/Th2 cytokine balance disturbances as compared with NP, and TH seems to be an intermediate step to PE.

Key words: Lymphocyte, Cytokine, Decidua, Pre-eclampsia, Transient hypertension

\section{Cytokine secretion by decidual lymphocytes in transient hypertension of pregnancy and pre-eclampsia}

\author{
Jacek R. Wilczyński 1,2,CA, Henryk Tchórzewski ${ }^{3,4}$, \\ Ewa GXowacka ${ }^{3}$, Małgorzata Banasi ${ }^{3}$, \\ Przemyslaw Lewkowicz ${ }^{3}$, Marian Szpakowski ${ }^{1,2}$, \\ Krzysztof Zeman ${ }^{5}$ and Jan Wilczyński ${ }^{6}$
}

${ }^{1}$ Department of Obstetrics and Gynecology,

${ }^{5}$ Department of Clinical Immunology, Institute of Basic Sciences, Military Medical Academy, Lodz, Poland; ${ }^{2}$ Department of Gynecological Surgery,

${ }^{3}$ Department of Clinical Immunology, and

${ }^{6}$ Department of Materno-Fetal Medicine, Polish

Mother's Health Center Research Institute, 93-338

Lodz, 281/289 Rzgowska St., Lodz, Poland; and

${ }^{4}$ Microbiology and Virology Center of Polish

Academy of Sciences, Lodz, Poland

\footnotetext{
${ }^{\mathrm{CA}}$ Corresponding Author

Tel/Fax: +48 422711221

E-mail: jrwil@post.pl
}

\section{Introduction}

Although the clinical presentations of pre-eclampsiaeclampsia and transient hypertension of pregnancy at least partially overlap, opinion exists that they are two distinct conditions ${ }^{1}$ with different pathophysiology $^{2-5}$ and outcome. ${ }^{6}$ However, epidemiological analysis indicates that approximately $15-25 \%$ of pregnant women initially diagnosed as having transient hypertension develop fully symptomatic pre-eclampsia later in pregnancy. ${ }^{7}$ This means that, in some patients, transient hypertension could probably represent an intermediate step in progression to pre-eclampsia.

The involvement of abnormal activation of the innate and acquired immune system in the pathogenesis of pre-eclampsia is well documented. ${ }^{8,9}$ The elevated serum level of interleukin (IL)-12, ${ }^{10}$ fetal monocyte activation 9 and deficiency of placental IL10 production $^{11}$ are responsible for enhanced $\mathrm{T}$ helper (Th)1-type cell maturation and hampered immunological tolerance of pre-eclamptic women to the foreign antigens of the fetus. The existence of a superantigen-like effect in a subset of patients ${ }^{12}$ supports the idea of the immunopathogenetical background of pre-eclampsia.

A widely accepted hypothesis originally presented by Wegman et al. ${ }^{13}$ underlines the crucial role of Th2activity cytokines in promoting successful pregnancy. Since that time, existence of the 'Th2-phenomenon' during normal human pregnancy has been confirmed by many authors. ${ }^{14-18}$ Pre-eclampsia is accompanied with elevated serum levels of Th1-type cytokines IL$12^{10}$ and tumor necrosis factor- $\alpha$ (TNF $\left.\alpha\right),{ }^{19}$ as well as Th2-type cytokine IL-6. ${ }^{19}$ Upregulation of Th1-activity responses was also shown 'in vitro' by increased interferon- $\gamma$ (IFN $\gamma),{ }^{14}$ IL-2 and TNF $\alpha^{14,20}$ production by peripheral blood lymphocytes. IL-2 and IL-12 stimulate Th1-like cell maturation ${ }^{21,22}$ and $\mathrm{TNF} \alpha$ may 
contribute for endothelial activation and failure observed in pre-eclampsia. ${ }^{19}$ The predominance of Th1-type activity was accompanied by the effect of decreased Th2-type suppressory cytokine IL-10 secretion by peripheral blood lymphocytes 'in vitro' ${ }^{20}$ as well as in placental samples. ${ }^{11}$ The investigations performed during pregnancy complicated with preeclampsia indicated that disturbances of cytokine Th1/Th2 balance are associated with elevated endothelin-1 levels followed by the presence of hypertension. ${ }^{23}$

None of the aforementioned studies refered to the autocrine pattern of Th1/Th 2 cytokine balance inside maternal decidua in pre-eclampsia and transient hypertension, and their potential role in understanding the local regulatory mechanisms seen in those two syndromes. To clarify this subject, we have focused our attention on comparison between spontaneous and mitogen-stimulated production of IL-2, IL4, IL-6, IL-10, IL-12 and IFN $\gamma$ in cultured lymhocytes isolated from third trimester decidua of healthy pregnant women, pre-eclamptics and those pregnant with transient hypertension. The obtained results have suggested that disturbances in autocrine regulation may be decisive for disease outcome.

\section{Materials and methods}

\section{Patients}

The study group was chosen from pregnant women who were hospitalized between September 1998 and January 2001 in three departments: the Department of Materno-Fetal Medicine, the Department of Perinatology and the Department of the Obstetrics of Polish Mother's Health Center Research Institute, Lodz, Poland.

Inclusion criteria were normal pregnancy, and pregnancy complicated with transient hypertension or pre-eclampsia. Pre-eclampsia was characterized by an increase in systolic pressure of $30 \mathrm{mmHg}$ or of diastolic pressure of $15 \mathrm{mmHg}$ compared with blood pressure measurements obtained before 20 gestational weeks (or, if these pressure levels were not known, a blood pressure of $140 / 90 \mathrm{mmHg}$ or greater obtained in two consecutive measurements $6 \mathrm{~h}$ apart after 20 gestational weeks), with concurrent proteinuria greater than $0.3 \mathrm{~g}$ per $24 \mathrm{~h}$ or greater than $30 \mathrm{mg} / \mathrm{dl}$ in a specimen. Transient hypertension was characterized by the same blood pressure measurements but without proteinuria or with proteinuria less than $0.3 \mathrm{~g}$ per $24 \mathrm{~h}^{1}$

Exclusion criteria were diabetes mellitus, gestational diabetes mellitus, renal diseases, chronic hypertension that predated pregnancy, infectious diseases recognized in the course of pregnancy, presence of premature or full-term uterine contractions, premature rupture of membranes or clinical chorioamnionitis. The pregnant women were not treated with corticosteroids before inclusion for the study. Establishment of such a wide range of exclusion criteria allowed us to eliminate possible clinical situations that could have a strong impact either on the composition of decidual lymphocytes or on the pattern of cytokine secretion.

Finally, 49 pregnant women were chosen for the study and, in all cases, the selection was made before decidual material was collected. All of them had been qualified for elective caesarean sections. In this group, 11 pregnant women had normal pregnancy (controls), 17 presented with transient hypertension of pregnancy and 21 with pre-eclampsia. Some of the data characterizing each group are presented in Table 1 . In the group of controls, the indications for elective caesarean sections were retinal degeneration changes, serious cardiac defects, pelvic deformations, cerebral vessels malformations, multifetal pregnancy and breech position in women with high-risk pregnancy. In the group of transiently hypertensive patients the most common indication

Table 1. Data from routine interview, clinical investigation, blood pressure measurements and laboratory testing in healthy pregnant women, and pregnant patients with transient hypertension and pre-eclampsia

\begin{tabular}{|c|c|c|c|}
\hline Parameter & $\begin{array}{c}\text { Normal } \\
\text { pregnancy } \\
(n=11)\end{array}$ & $\begin{array}{c}\text { Transient } \\
\text { hypertension } \\
(n=17)\end{array}$ & $\begin{array}{c}\text { Pre-eclampsia } \\
\qquad(n=21)\end{array}$ \\
\hline Patient age (years) & $29.5 \pm 5.7$ & $28.6 \pm 5.3$ & $28.7 \pm 6.1$ \\
\hline Gestational age (weeks) & $36.5 \pm 4.9$ & $35.1 \pm 3.5$ & $33.3 \pm 2.7$ \\
\hline Primigravidae (n) & 8 & 13 & 16 \\
\hline Mean systolic pressure $(\mathrm{mmHg})$ & $127.0 \pm 7.8$ & $171.9 \pm 15.8$ & $178.5 \pm 21.9$ \\
\hline Mean diastolic pressure $(\mathrm{mmHg})$ & $78.7 \pm 7.7$ & $107.1 \pm 10.8$ & $111.6 \pm 12.3$ \\
\hline Proteinuria (mg/dl) & - & $28.3 \pm 2.9$ & $509.9 \pm 851.7$ \\
\hline Proteinuria/24 h (g/24 h) & - & - & $4.9 \pm 6.1$ \\
\hline Serum uric acid (mg/dl) & $3.8 \pm 1.3$ & $5.7 \pm 2.0$ & $7.0 \pm 1.9$ \\
\hline Platelet count (G/I) & $235.7 \pm 43.8$ & $208.8 \pm 40.9$ & $204.7 \pm 55.6$ \\
\hline Serum aspargin aminotransferase (IU/I) & $27.9 \pm 4.1$ & $40.7 \pm 19.8$ & $54.5 \pm 30.8$ \\
\hline Serum alanin aminotransferase (IU/I) & $17.4 \pm 15.2$ & $27.6 \pm 13.2$ & $62.4 \pm 55.2$ \\
\hline
\end{tabular}


was severe hypertension complicated with cardiotocographic signs of fetal distress, while in preeclamptic patients the indications were symptoms of imminent eclampsia and/or cardio-tocographic signs of threaten fetal asphyxia. All patients gave written and informed consent for participation in clinical research and the agreement of the Polish Mother's Health Center Research Institute Ethical Commitee for performing the study was obtained.

\section{Cell isolation}

Third-trimester maternal decidual tissue was obtained by curettage of uterine cavity during caesarean sections. The blood clots and fragments of the fetal membranes were removed macroscopically using sterile pincers. Then the samples were placed into bottles containing sterile phosphate-buffered saline (PBS) (WSS, Lublin, Poland). Some of the collected samples after initial washing in PBS were randomly submitted to histopathological examination, which revealed that trophoblastic villi were present in less than $5 \%$ of the specimen volume, giving the certainty that samples contained almost pure decidua. Inside laminar flow cabinet decidual slices were rinsed several times in PBS to remove residual blood and than mechanically disaggregated to fragments of approximately $3-10 \mathrm{~mm}^{3}$ volume. Subsequent decidual cell suspensions were prepared by an electromechanical dispersal method using Medimachine (Dako, Copenhagen, Denmark). Tissue fragments with $1.5 \mathrm{ml}$ PBS were placed in the Medicon disaggregator chamber (Dako) with $50 \mu \mathrm{m}$ of separator mesh. The optimal time of disaggregation was $20 \mathrm{sec}$. Cell suspensions were filtered using disposable sterile Filcon (Dako) with a 50-70 $\mu \mathrm{m}$ pore size range and washed twice to eliminate cell debris. To isolate lymphocytes, cell suspensions were centrifugated using the standard gradient sedimentation technique on Gradisol G (Polfa, Kutno, Poland). Isolated lymphocytes were washed and suspended in PBS in a final density of $1.0 \times 10^{5}$ cells $/ \mathrm{ml}$. The viability of the cells in suspension was about $98 \%$, as tested with the trypan-blue exclusion method.

\section{Lymphocyte subset analysis}

Monoclonal antibodies labeled with fluorescein isothiocyanate (FITC) or phycoerytrin (PE) were used in the study. One-color or two-color immunofluorescence staining was performed with the use of the following antibodies (Becton-Dickinson, San Jose, CA, USA): anti-CD3 (against mature $\mathrm{T}$ lymphocytes), antiCD19 (against B lymphocytes), anti-CD4/CD8 (against helper/inducer and suppressor/cytotoxic lymphocytes), and anti-CD56/CD16 (against natural killer (NK) cells). Flow cytometry was performed on FACSCalibur (Beckton-Dickinson) with a $488 \mathrm{~nm}$ argon laser. Optimal scatter gates were set using LeucoGATE (anti-CD45 FITC and anti-CD14 PE; Becton-Dickinson) so that analysis gate for cells included more than $96 \%$ of lymphocytes and less than 3\% of monocytes/granulocytes. For background control, immunoglobulin (Ig)G1 FITC and IgG2a PE (Becton-Dickinson) were used. No less than $1 \times 10^{4}$ cells were measured in each analysis. The results are presented as the percentage of positive cells in the tested sample.

\section{Cytokine production}

Isolated decidual lymphocytes $\left(1.0 \times 10^{5}\right.$ cells $\left./ \mathrm{ml}\right)$ were placed in culture medium: RPMI 1640 (Flow) enriched with $10 \%$ fetal calf serum (Sigma, St Louis, MO, USA), $2 \mathrm{mM}$ L-glutamine (Serva, Heidelberg, Germany), and antibiotics $(100 \mathrm{U} / \mathrm{ml}$ of penicillin, $10 \mu \mathrm{g} / \mathrm{ml}$ of streptomycin). To stimulate lymphocyte proliferation, phytohaemaglutinine (PHA) (Sigma) in a concentration of $5 \mu \mathrm{g} / \mathrm{ml}$ of culture medium was used. Cultures were conducted in flat-bottomed microplates (Nunc, Kamstrupvij, Denmark) using $10^{5}$ cells/100 $\mu \mathrm{l}$ of medium, for $72 \mathrm{~h}$ in humidified air with $5 \% \mathrm{CO}_{2}$ (Assab, Stockholm, Sweden), and each experiment carried out in triplicate. Control triplicates had no mitogen added. At the end of the culture, microplates were centrifugated at $2000 \times g$ for $10 \mathrm{~min}$. Then the culture supernatant was collected and frozen at $-80^{\circ} \mathrm{C}$. A standard immunoenzymatic enzyme-linked immunosorbent assay method was used for estimation of IL-2, IL-6, IL-10, IL-12, IFN $\gamma$ (ENDOGEN, Minneapolis, MN, USA) and IL-4 (Hybridomus; Cytotech, Copenhagen, Denmark) concentrations. The results are presented as picograms per milliliter. The minimal detection limits for cytokines were as follows: $<6 \mathrm{pg} / \mathrm{ml}$ for IL-2, $1.1 \mathrm{pg} / \mathrm{ml}$ for IL- $4,<1 \mathrm{pg} / \mathrm{ml}$ for IL- $6,<3 \mathrm{pg} / \mathrm{ml}$ for IL$10,<5 \mathrm{pg} / \mathrm{ml}$ for IL-12, and $<2 \mathrm{pg} / \mathrm{ml}$ for IFN $\gamma$. Intraassay and inter-assay coefficients of variation for all studied cytokines were $<10 \%$.

\section{Statistical analysis}

Results are reported as the group median with cut-off points of $25 \%$ and $75 \%$ of results. Analysis of differences between three groups was initially carried out using the Kruskal-Wallis test. Than the MannWhitney $\mathrm{U}$ test $(p<0.05)$ was performed as appropriate to test for the statistical significance of differences between each pair of groups. We used licensed Statistica 5.0 for Windows.

\section{Results}

The examples of the main maternal lymphocyte subsets obtained during isolation from third-trimester decidual tissue are presented in Table 2. Pre-eclamptic patients, compared with controls and those pregnant and with transient hypertension, were characterized with significantly increased percentage of classical 
Table 2. The percentage of main decidual lymphocyte subsets in the group of healthy pregnant women, and pregnant patients with transient hypertension and pre-eclampsia

\begin{tabular}{|c|c|c|c|c|}
\hline $\begin{array}{l}\text { Decidual } \\
\text { lymphocyte } \\
\text { subsets (\%) }\end{array}$ & $\begin{array}{c}\text { (1) Normal } \\
\text { pregnancy } \\
(n=11)\end{array}$ & $\begin{array}{l}\text { (2) Transient } \\
\text { hypertension } \\
(n=17)\end{array}$ & $\begin{array}{l}\text { (3) Pre-eclampsia } \\
(n=21)\end{array}$ & $p$ \\
\hline $\mathrm{CD}^{+}$ & $\begin{array}{c}58.0 \\
(55.0 / 62.0)\end{array}$ & $\begin{array}{c}56.0 \\
(49.0 / 62.0)\end{array}$ & $\begin{array}{c}32.0 \\
(26.0 / 50.0)\end{array}$ & $\begin{array}{l}(1)-(2), \text { NS } \\
(1)-(3),<0.0004 \\
(2)-(3),<0.0006\end{array}$ \\
\hline $\mathrm{CD}_{19}{ }^{+}$ & $\begin{array}{c}3.0 \\
(2.0 / 5.0)\end{array}$ & $\begin{array}{c}3.0 \\
(2.0 / 4.0)\end{array}$ & $\begin{array}{c}1.0 \\
(1.0 / 2.0)\end{array}$ & $\begin{array}{l}(1)-(2), \text { NS } \\
(1)-(3),<0.02 \\
(2)-(3),<0.005\end{array}$ \\
\hline $\mathrm{CD}^{+}$ & $\begin{array}{c}25.0 \\
(22.0 / 28.0)\end{array}$ & $\begin{array}{c}26.0 \\
(24.0 / 31.0)\end{array}$ & $\begin{array}{c}19.0 \\
(13.0 / 26.0)\end{array}$ & $\begin{array}{l}(1)-(2), N S \\
(1)-(3), N S \\
(2)-(3), N S\end{array}$ \\
\hline $\mathrm{CD}^{+}$ & $\begin{array}{c}26.0 \\
(24.0 / 30.0)\end{array}$ & $\begin{array}{c}23.0 \\
(20.0 / 28.0)\end{array}$ & $\begin{array}{c}26.0 \\
(24.0 / 36.0)\end{array}$ & $\begin{array}{l}(1)-(2),<0.04 \\
(1)-(3), \text { NS } \\
(2)-(3),<0.05\end{array}$ \\
\hline NK cells & $\begin{array}{c}35.0 \\
(32.0 / 38.0)\end{array}$ & $\begin{array}{c}24.0 \\
(20.0 / 33.0)\end{array}$ & $\begin{array}{c}57.0 \\
(45.0 / 62.0)\end{array}$ & $\begin{array}{l}(1)-(2),<0.02 \\
(1)-(3),<0.002 \\
(2)-(3),<0.00003\end{array}$ \\
\hline
\end{tabular}

Data presented as median (25\%/75\%). CD3 ${ }^{+}$, Lymphocyte T; CD19+, lymphocyte B; CD4 ${ }^{+}$, helper/inducer lymphocytes; CD8 ${ }^{+}$, suppressor/cytotoxic lymphocytes; NK cells, classical natural killer $\mathrm{CD}^{-} / \mathrm{CD} 56^{+} \mathrm{CD} 16^{+}$cells; NS, difference statistically unsignificant.

$\mathrm{NK} \mathrm{CD} 3^{-} / \mathrm{CD} 56^{+} 16^{+}$cells and decreased percentage of mature $\mathrm{CD}^{+} \mathrm{T}$ and $\mathrm{CD} 19^{+} \mathrm{B}$ lymphocytes.

The concentrations of cytokines secreted spontaneously to supernatant of cultured decidual lymphocytes are compared in Table 3 and presented graphically in Figs 1, 3, 5, and 7. Analysis indicated significantly decreased levels of IL- 6 and IL-10 in preeclamptic patients as well as increased level of IFN $\gamma$ in patients suffering from both transient hypertension and pre-eclampsia.

The concentrations of cytokines secreted on mitogen stimulation of cultured decidual lymphocytes are presented in Table 4 and presented graphically in Figs $2,4,6$, and 8. Lymphocytes of pre-eclamptic women secreted significantly decreased amounts of IL-6, IL-10 and IL-12 but extremely increased amounts of IFN $\gamma$.

Table 3. Spontaneous cytokine secretion (pg/ml) from cultured decidual lymphocytes of normal pregnant women, and pregnant patients with transient hypertension and pre-eclampsia

\begin{tabular}{|c|c|c|c|c|}
\hline Cytokine & $\begin{array}{l}\text { (1) Normal } \\
\text { pregnancy } \\
(n=11)\end{array}$ & $\begin{array}{l}\text { (2) Transient } \\
\text { hypertension } \\
(n=17)\end{array}$ & $\begin{array}{l}\text { (3) Pre-eclampsia } \\
(n=21)\end{array}$ & $p$ \\
\hline IL-2 & $\begin{array}{c}0.0 \\
(0.0 / 0.0)\end{array}$ & $\begin{array}{c}0.0 \\
(0.0 / 5.9)\end{array}$ & $\begin{array}{c}0.0 \\
(0.0 / 0.0)\end{array}$ & $\begin{array}{l}(1)-(2), N S \\
(1)-(3), N S \\
(2)-(3), N S\end{array}$ \\
\hline IL-4 & $\begin{array}{c}0.0 \\
(0.0 / 0.0)\end{array}$ & $\begin{array}{c}0.0 \\
(0.0 / 0.0)\end{array}$ & $\begin{array}{c}0.0 \\
(0.0 / 0.0)\end{array}$ & $\begin{array}{l}(1)-(2), N S \\
(1)-(3), N S \\
(2)-(3), N S\end{array}$ \\
\hline IL-6 & $\begin{array}{c}1661.5 \\
(1115.0 / 1957.0)\end{array}$ & $\begin{array}{c}1454.2 \\
(1165.0 / 4090.0)\end{array}$ & $\begin{array}{c}720.0 \\
(111.2 / 1147.0)\end{array}$ & $\begin{array}{l}(1)-(2), \text { NS } \\
(1)-(3),<0.002 \\
(2)-(3),<0.0008\end{array}$ \\
\hline IL-10 & $\begin{array}{c}115.0 \\
(53.3 / 267.5)\end{array}$ & $\begin{array}{c}128.5 \\
(9.4 / 394.0)\end{array}$ & $\begin{array}{c}41.0 \\
(12.5 / 89.0)\end{array}$ & $\begin{array}{l}(1)-(2), \text { NS } \\
(1)-(3),<0.05 \\
(2)-(3), \text { NS }\end{array}$ \\
\hline IL-12 & $\begin{array}{c}16.0 \\
(0.0 / 17.8)\end{array}$ & $\begin{array}{c}12.0 \\
(3.3 / 16.9)\end{array}$ & $\begin{array}{c}12.5 \\
(0.0 / 23.7)\end{array}$ & $\begin{array}{l}(1)-(2), N S \\
(1)-(3), N S \\
(2)-(3), N S\end{array}$ \\
\hline $\mathrm{IFN} \gamma$ & $\begin{array}{c}0.0 \\
(0.0 / 0.5)\end{array}$ & $\begin{array}{c}7.6 \\
(0.0 / 35.4)\end{array}$ & $\begin{array}{c}3.9 \\
(0.0 / 21.0)\end{array}$ & $\begin{array}{l}(1)-(2),<0.03 \\
(1)-(3), 0.05 \\
(2)-(3), \text { NS }\end{array}$ \\
\hline
\end{tabular}


Table 4. PHA-stimulated cytokine secretion $(\mathrm{pg} / \mathrm{ml})$ from cultured decidual lymphocytes of normal pregnant women, and pregnant patients with transient hypertension and pre-eclampsia

\begin{tabular}{|c|c|c|c|c|}
\hline Cytokine & $\begin{array}{c}\text { (1) Normal } \\
\text { pregnancy } \\
(n=11)\end{array}$ & $\begin{array}{l}\text { (2) Transient } \\
\text { hypertension } \\
(n=17)\end{array}$ & $\begin{array}{l}\text { (3) Pre-eclampsia } \\
(n=21)\end{array}$ & $P$ \\
\hline IL-2 & $\begin{array}{c}565.4 \\
(285.2 / 802.9)\end{array}$ & $\begin{array}{c}311.0 \\
(8.6 / 700.6)\end{array}$ & $\begin{array}{c}624.0 \\
(316.9 / 960.8)\end{array}$ & $\begin{array}{l}(1)-(2), N S \\
(1)-(3), N S \\
(2)-(3), N S\end{array}$ \\
\hline IL-4 & $\begin{array}{c}17.8 \\
(14.8 / 39.1)\end{array}$ & $\begin{array}{r}51.5 \\
(21.3 / 78.6)\end{array}$ & $\begin{array}{c}30.0 \\
(17.2 / 48.6)\end{array}$ & $\begin{array}{l}(1)-(2), 0.06 \\
(1)-(3), N S \\
(2)-(3), N S\end{array}$ \\
\hline IL-6 & $\begin{array}{c}7211.0 \\
(6186.0 / 7990.0)\end{array}$ & $\begin{array}{c}7559.5 \\
(5930.0 / 9268.7)\end{array}$ & $\begin{array}{c}3295.2 \\
(582.0 / 6416.4)\end{array}$ & $\begin{array}{l}(1)-(2), \text { NS } \\
(1)-(3),<0.02 \\
(2)-(3),<0.002\end{array}$ \\
\hline IL-10 & $\begin{array}{c}1046.2 \\
(645.6 / 1548.2)\end{array}$ & $\begin{array}{c}1015.0 \\
(330.0 / 1865.0)\end{array}$ & $\begin{array}{c}282.0 \\
(155.2 / 680.0)\end{array}$ & $\begin{array}{l}(1)-(2), \text { NS } \\
(1)-(3),<0.002 \\
(2)-(3),<0.008\end{array}$ \\
\hline IL-12 & $\begin{array}{c}436.6 \\
(151.0 / 491.2)\end{array}$ & $\begin{array}{c}209.8 \\
(92.4 / 417.0)\end{array}$ & $\begin{array}{c}212.7 \\
(79.6 / 300.4)\end{array}$ & $\begin{array}{l}(1)-(2), \text { NS } \\
(1)-(3),<0.05 \\
(2)-(3), N S\end{array}$ \\
\hline $\mathrm{IFN} \gamma$ & $\begin{array}{c}2950.3 \\
(1018.9 / 13249.2)\end{array}$ & $\begin{array}{c}24850.0 \\
(3105.8 / 45850.0)\end{array}$ & $\begin{array}{c}44201.0 \\
(41980.0 / 76450.0)\end{array}$ & $\begin{array}{l}(1)-(2), 0.06 \\
(1)-(3),<0.0002 \\
(2)-(3),<0.02\end{array}$ \\
\hline
\end{tabular}

Data presented as median (25\%/75\%). NS, Difference statistically unsignificant.

\section{Discussion}

Our study, in concordance with previous investigations performed on cultured peripheral blood mononuclear cells (PBMCs), ${ }^{14,20}$ revealed that also lymphocytes isolated from decidua of pre-eclamptic patients are capable of producing, spontaneously and after PHA stimulation, large amounts of IFN $\gamma$. IFN $\gamma$ belongs to cytokines of strong Th1-like activity and is mainly produced by $\mathrm{T}$ lymphocytes and activated decidual NK cells. ${ }^{22}$ Because PHA is believed to exert its mitogenic effects mainly on $\mathrm{T}$ lymphocytes, it is possible that increased levels of IFN $\gamma$ origin from NK cells activated vigorously by intercellular regulatory signals sent by $\mathrm{T}$ cells. Increased concentrations of this cytokine are harmful for pregnancy, causing fetal resorptions in the mice model of recurrent spontaneous abortions, ${ }^{24}$ and could also be responsible for induction of trophoblast apoptosis. ${ }^{25}$ Decreased IFN $\gamma$ production by PBMCs was noted in pregnant women in remission of rheumatoid arthritis. ${ }^{26}$ Of all investigated cytokines, only IFN $\gamma$ is significantly increased when patients with transient hypertension are compared with normotensive pregnant controls. Despite the lack of changes concerning the rest of the investigated cytokines, this result indicates the presence of a prominent local Th1 shift ${ }^{27,28}$ in transient hypertension similar to that existing in pre-eclampsia. The diminished production of IL- 6 and IL-10 observed in our study indicates downregulation of Th2-type activity in decidual tissue, which is supplementary to that observed in peripheral blood ${ }^{20}$ and placenta ${ }^{29}$ during pre-eclamptic pregnancy, and may result in
IFN $\gamma$ overproduction. Deficiency in IL-6 secretion observed during pre-eclampsia lowers trophoblastic hCG production and causes defective placental development. ${ }^{25}$ Lowered IL-10 production in pre-eclampsia could be associated with heightened maternal antifoetal immunity and inadequate placental development. ${ }^{11} \mathrm{IL}-12$ promotes the potential of CD4T cells to produce IFN $\gamma$; however, decreased IL-12 production does not result in inhibition of IFN $\gamma$ secretion, ${ }^{30}$ which is confirmed by our results.

Lymphocyte subset analysis indicates that the decidua of pre-eclamptic patients contains increased numbers of classical NK cells. This remains in agreement with results obtained by Stallmach et al. ${ }^{31}$ who found out that in pre-eclamptic patients NK $\mathrm{CD}^{2} 6^{+}$cells constituted more than $40 \%$ of decidua infiltrating cells. The co-existence of a lowered $\mathrm{CD}^{+}$ $\mathrm{T}$ subset percentage together with $\mathrm{NK}$ population shift could be responsible for the observed cytokine disbalance. ${ }^{32}$ Very low representation of decidual $\mathrm{CD} 19^{+} \mathrm{B}$ lymphocytes in pre-eclampsia argues against thesis $^{33}$ of their possible role in pathogenesis of this syndrome. The classical $\mathrm{NK} \mathrm{CD}^{-} / \mathrm{CD}^{2} 6^{+} 16^{+}$cells are more abundant in the decidua of healthy pregnant subjects then in pregnant women with transient hypertension. The candidate for local immunoregulatory mechanism inhibiting NK proliferation is antigen HLA-G, whose expression on the trophoblastic surface in the cases of transient hypertension is higher compared with pre-eclampsia. ${ }^{34}$

Taking into consideration the disturbances of local cytokine production by decidual lymphocytes 'in vitro', we conclude that transient hypertension 


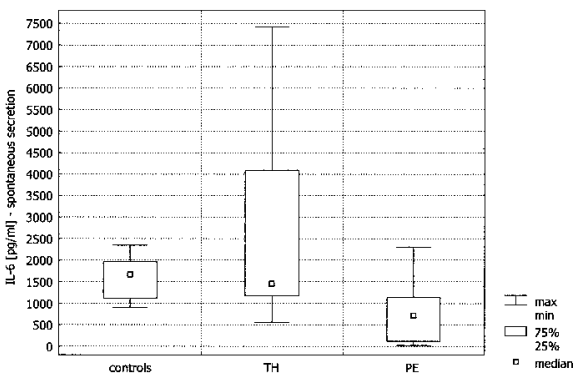

FIG. 1. Comparison of IL-6 spontaneous secretion in healthy pregnant women (controls) $(n=11)$, and pregnant women with transient hypertension (TH) $(n=17)$ and pre-eclampsia (PE) $(n=21)$. Statistically significant are the differences between controls and PE $(p<0.002)$ and between TH and PE $(p<0.0008)$.

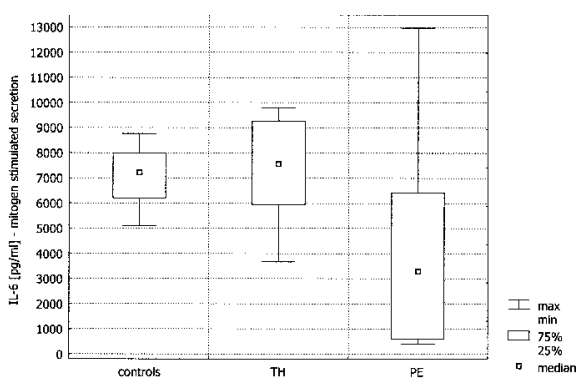

FIG. 2. Comparison of IL-6 PHA-stimulated secretion in healthy pregnant women (controls) $(n=11)$, and pregnant women with transient hypertension (TH) $(n=17)$ and preeclampsia (PE) $(n=21)$. Statistically significant are the differences between controls and PE $(p<0.02)$ and between TH and PE $(p<0.002)$.

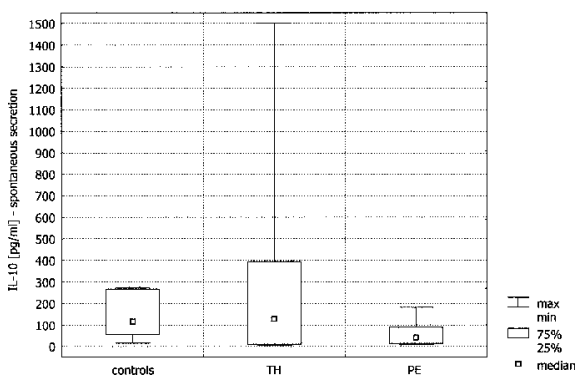

FIG. 3. Comparison of IL-10 spontaneous secretion in healthy pregnant women (controls) $(n=11)$, and pregnant women with transient hypertension (TH) $(n=17)$ and pre-eclampsia (PE) $(n=21)$. Statistically significant are the differences between controls and PE $(p<0.05)$.

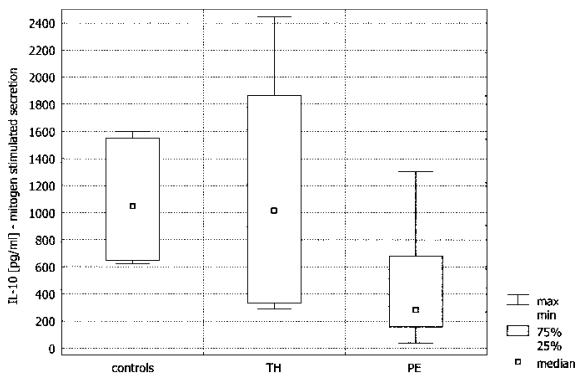

FIG. 4. Comparison of IL-10 PHA-stimulated secretion in healthy pregnant women (controls) $(n=11)$, and pregnant women with transient hypertension (TH) $(n=17)$ and preeclampsia (PE) $(n=21)$. Statistically significant are the differences between controls and PE $(p<0.002)$ and between TH and PE $(p<0.008)$.

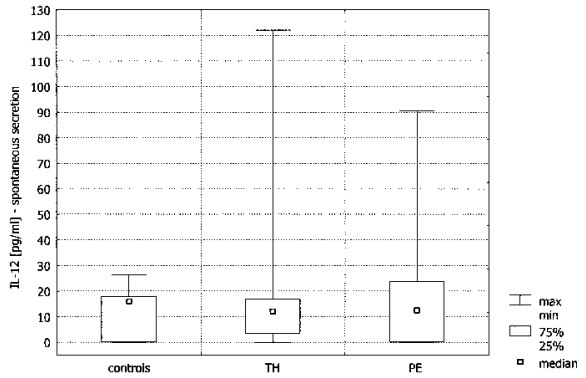

FIG. 5. Comparison of IL-12 spontaneous secretion in healthy pregnant women (controls) $(n=11)$, and pregnant women with transient hypertension (TH) $(n=17)$ and pre-eclampsia (PE) $(n=21)$. The differences between all groups studied are not statistically significant

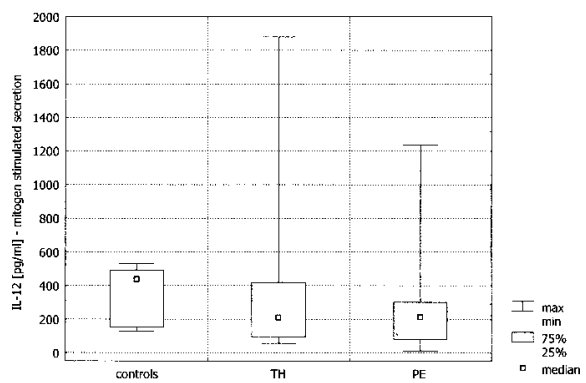

FIG. 6. Comparison of IL-12 PHA-stimulated secretion in healthy pregnant women (controls) $(n=11)$, and pregnant women with transient hypertension (TH) $(n=17)$ and preeclampsia (PE) $(n=21)$. Statistically significant are the differences between controls and $\operatorname{PE}(p<0.05)$.

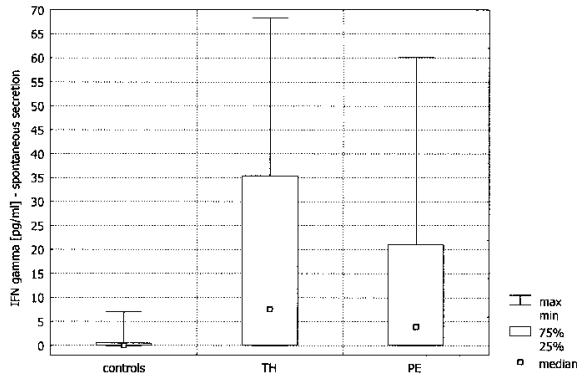

FIG. 7. Comparison of IFN $\gamma$ spontaneous secretion in healthy pregnant women (controls) $(n=11)$, and pregnant women with transient hypertension $(\mathrm{TH})(n=17)$ and pre-eclampsia (PE) $(n=21)$. Statistically significant are controls and $\mathrm{TH}(p<$ 0.03).

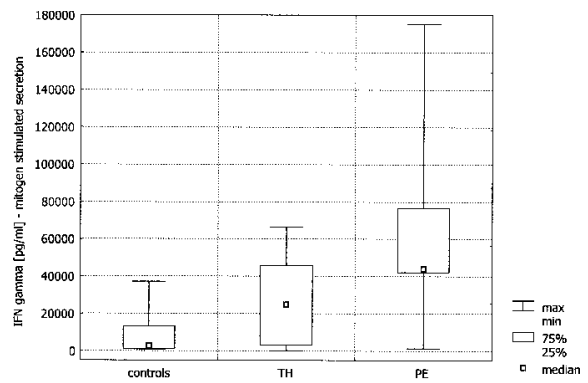

FIG. 8. Comparison of IFN $\gamma$ PHA-timulated secretion in healthy pregnant women (controls) $(n=11)$, and pregnant women with transient hypertension $(\mathrm{TH})(n=17)$ and preeclampsia (PE) $(n=21)$. Statistically significant are the differences between controls and PE $(p<0.0002)$ and between TH and PE $(p<0.02)$. 
constitutes an intermediate step in the etiology of preeclampsia and is like pre-eclampsia characterized by a disturbed Th1/Th2 balance, although intensity of these disturbances is different in each syndrome.

ACKNOWLEDGEMENTS. The authors express their gratitude to Prof. Przemyslaw Oszukowski and Prof. Grzegorz Krasomski who provided the pregnant subjects studied. The work was sponsored by a KBN 4 P05E 11815 grant.

\section{References}

1. Zamorski MA, Green LA. NHBPEP report on high blood pressure in pregnancy: a summary for family physicians. Am Family Physician 2001; 64: $263-270$.

2. Zamorski MA, Green LA. Preeclampsia and hypertensive disorders of pregnancy. Am Family Physician 1996; 53: 1595-1610.

3. D'Anna R, Baviera G, Scilipoti A, Leonardi I, Leo R. The clinical utility of serum uric acid measurements in pre-eclampsia and transient hypertension in pregnancy. Panminerva Med 2000; 42: 101-103.

4. Higgins JR, Papayianni A, Brady HR, Darling MR, Walshe JJ. Circulating vascular cell adhesion molecule-1 in pre-eclampsia, gestational hypertension, and normal pregnancy: evidence of selective dysregulation of vascular cell adhesion molecule-1 homeostasis in pre-eclampsia. Am J Obstet Gynecol 1998; 179: 464-469.

5. Krauss T, Kuhn W, Lakoma C, Augustin HG. Circulating endothelial cell adhesion molecules as diagnostic markers for the early identification of pregnant women at risk for development of preeclampsia. Am J Obste Gynecol 1997; 177: 443-449.

6. Terrone DA, Rinehart BK, May WL, Martin RW, Martin JN Jr. The myth of transient hypertension: descriptor or disease process? Am J Perinatol 2001; 18: 73-77.

7. Saudan P, Brown MA, Buddle ML, Jones M. Does gestational hypertension become pre-eclampsia? Br J Obstet Gynaecol 1998; 105: 1177-1184.

8. Sacks GP, Sargent IL, Redman CWG. An innate view of human pregnancy. Immunol Today 1999; 20: 114-118.

9. Steinborn A, Sohn C, Sayehli C, Niederhut A, Schmitt E, Kaufmann M. Preeclampsia, a pregnancy-specific disease, is associated with fetal monocyte activation. Clin Immunol 2001; 100: 305-313.

10. Daniel Y, Kupferminc MJ, Baram A, Jaffa AJ, Fait G, Wolman I, Lessing JB. Plasma interleukin-12 is elevated in patients with preeclampsia. Am Reprod Immunol 1998; 39: 376-380.

11. Hennessy A, Pilmore HL, Simmons LA, Painter DM. A deficiency of placental IL-10 in preeclampsia. I Immunol 1999; 163: 3491-3495.

12. Luppi P, McKnight C, Mathie T, Faas S, Rudert WA, Stewart-Akers AM, Trucco M, DeLoia JA. Evidence for superantigen involvement in preeclampsia. Am J Reprod Immunol 2000; 43: 187-196.

13. Wegmann TG, Lin H, Guilbert L, Mosmann TR. Bidirectional cytokine interactions in the maternal-fetal relationship: is successful pregnancy a Th2 phenomenon? Immunol Today 1993; 14: 353-356.

14. Saito S, Sakai M, Sasaki Y, Tanebe K, Tsuda H, Michimata T. Quantitative analysis of peripheral blood Th0, Th1, Th2 and the Th1:Th2 cell ratio during normal human pregnancy and preeclampsia. Clin Exp Immunol 1999; 117: 550-555.

15. Piccini MP, Maggi E, Romagnani S. Role of hormone-controlled T-cell cytokines in the maintenance of pregnancy. Biochem Soc Trans 2000; 28: $212-215$.

16. Marzi M, Vigano A, Trabattoni D, Villa ML, Salvaggio A, Clerici E, Clerici M. Characterization of type 1 and type 2 cytokine production profile in physiologic and pathologic human pregnancy. Clin Exp Immunol 1996; 106: $127-133$.
17. Tranchot-Diallo J, Gras G, Parnet-Mathieu F, Benveniste O, Marce D, Roques P, Milliez J, Chaouat G, Dormont D. Modulations of cytokine expression in pregnant women. Am J Reprod Immunol 1997; 37: 215-226.

18. Szekeres-Bartho J, Faust Z, Varga P, Szereday L, Kelemen K. The immunological pregnancy protective effect of progesterone is manifested via controlling cytokine production. Am J Reprod Immunol 1996; 35: 348-351.

19. Conrad KP, Miles TM, Benyo DF. Circulating levels of immunoreactive cytokines in women with preeclampsia. Am J Reprod Immunol 1998; 40: 102-111.

20. Darmochwal-Kolarz D, Leszczynska-Gorzelak B, Rolinski J, Oleszczuk J. T helper 1- and T helper 2-type cytokine imbalance in pregnant women with pre-eclampsia. Eur J Obstet Gynecol Reprod Biol 1999; 86: 165-170.

21. Clark DA, Arck PC, Jalali R, Merali FS, Manuel J, Chaouat G, Underwood JL, Mowbray JF. Psycho-neuro-cytokine/endocrine pathways in immunoregulation during pregnancy. Am J Reprod Immunol 1996; 35: $330-337$.

22. Trinchieri G. Interleukin-12 and its role in the generation of Th1 cells. Immunol Today 1993; 14: 335-338.

23. Kuwajima T, Suzuki S, Yoneyama Y, Sawa R, Asakura H, Araki T. Relation between plasma endothelin 1 levels and $\mathrm{T}$ helper 1:T helper 2 cell immunity in women with preeclampsia. Gynecol Obstet Invest 2001; 52: $260-263$.

24. Clark DA, Chaouat G, Arck PC, Mittruecker HW, Levy GA. Cytokinedependent abortion in CBAxDBA/2 mice is mediated by the procoagulant fgl2 prothombinase. J Immunol 1998; 160: 545-549.

25. Bennett WA, Lagoo-Deenadayalan S, Brackin MN, Hale E, Cowan BD. Cytokine expression by models of human trophoblast as assessed by a semiquantitative reverse transcription-polymerase chain reaction technique. Am J Reprod Immunol 1996; 36: 285-294.

26. Tchórzewski H, Krasomski G, Biesiada L, Glowacka E, Banasik M, Lewkowicz P. IL-12, IL-6 and IFN- $\gamma$ production by lymphocytes of pregnant women with rheumatoid arthritis remission during pregnancy. Mediat Inflamm 2000; 9: 289-293.

27. Belardelli F. Role of interferons and other cytokines in the regulation of the immune response. APMIS 1995; 103: 161-179.

28. Del Prete G, Maggi E, Romagnani S. Human Th 1 and Th 2 cells: functional properties, mechanisms of regulation and role in disease. Labor Invest 1994; 70: 299-306

29. Kauma SW, Wang Y, Walsh SW. Preeclampsia is associated with decreased placental interleukin-6 production. J Soc Gynecol Investig 1995; 2: 614-617.

30. McRae BL, Semnani RT, Hayes MP, van Seventer GA. Type I IFNs inhibit human dendritic cell IL-12 production and Th1 cell development. $J$ Immunol 1998; 160: 4298-4304.

31. Stallmach T, Hebisch G, Orban P, Lu X. Aberrant positioning of trophoblast and lymphocytes in the feto-maternal interface with preeclampsia. Virchows Arch 1999; 434: 207-211.

32. Chaouat G, Tranchot-Diallo J, Volumenie JL, Menu E, Gras G, Delage G, Mognetti B. Immune suppression and Th1/Th2 balance in pregnancy revisited: a (very) personal tribute to Tom Wegmann. Am J Reprod Immunol 1997; 37: 427-434.

33. Matthiesen L, Berg G, Ernerudh J, Häkansson L. Lymphocyte subsets and mitogen stimulation of blood lymphocytes in preeclampsia. Am J Reprod Immunol 1999; 41: 192-203.

34. Colbern GT, Chiang MH, Main EK. Expression of the nonclasic histocompatibility antigen HLA-G by preeclamptic placenta. Am J Obstet Gynecol 1994; 170: 1244-1250.

\section{Received 19 November 2001}

Accepted 11 February 2002 


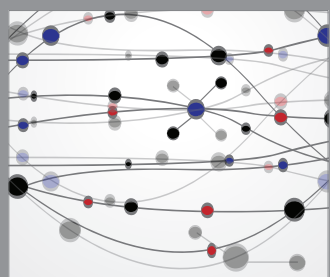

The Scientific World Journal
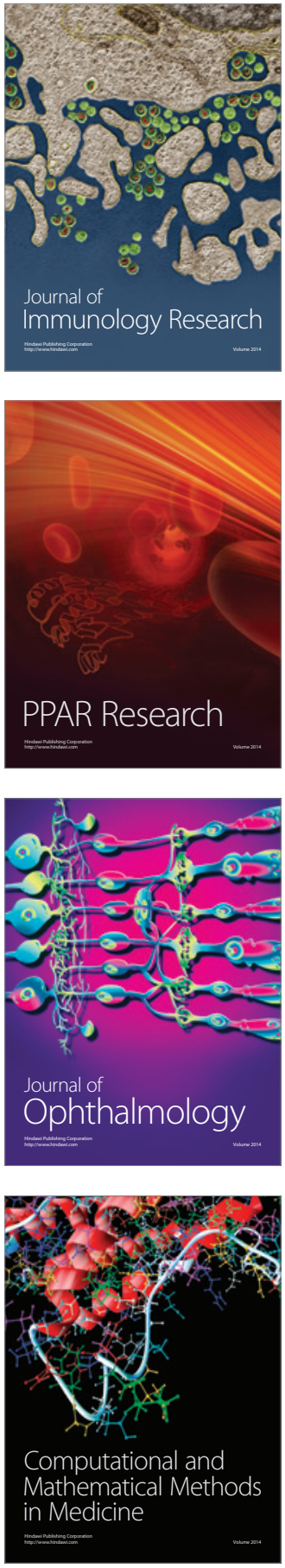

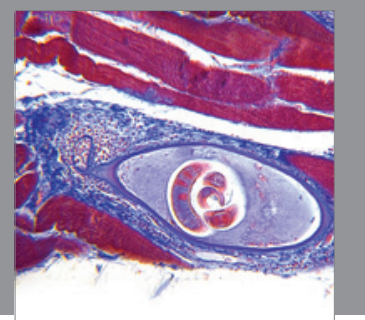

Gastroenterology

Research and Practice
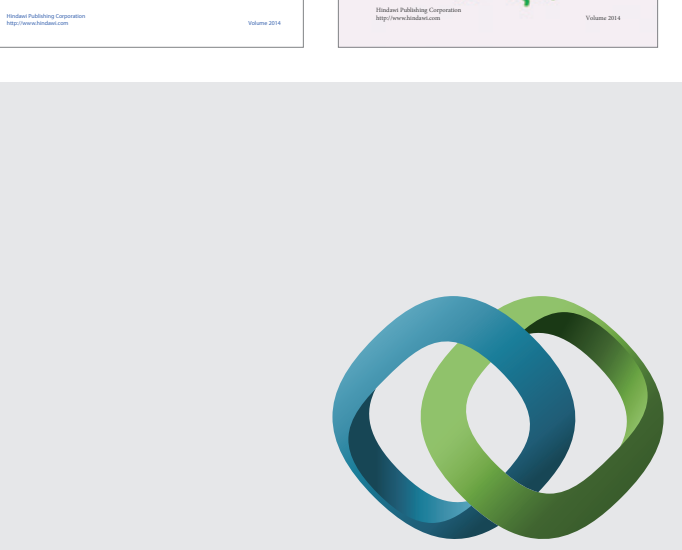

\section{Hindawi}

Submit your manuscripts at

http://www.hindawi.com
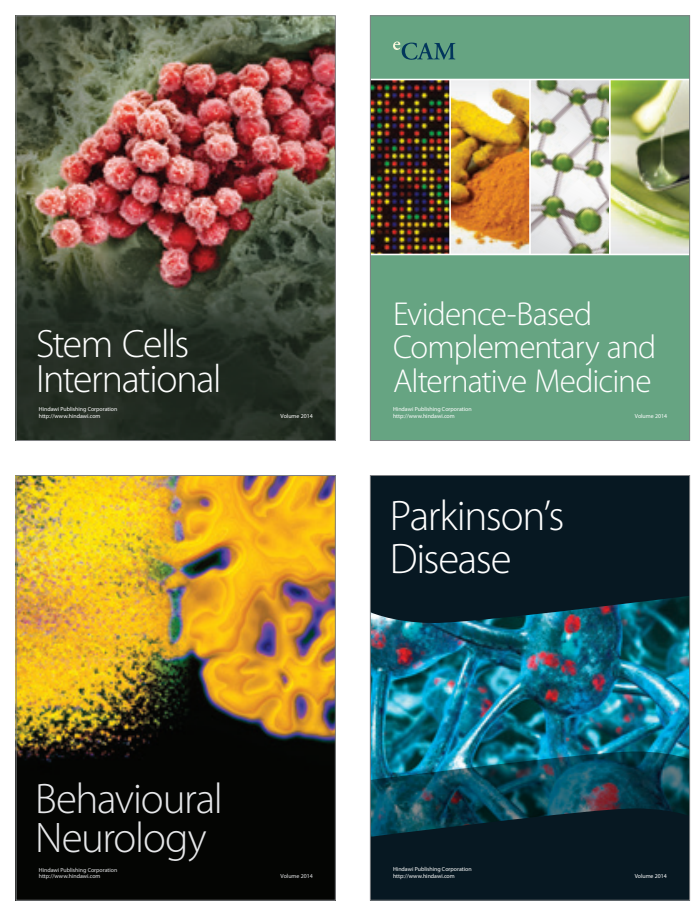

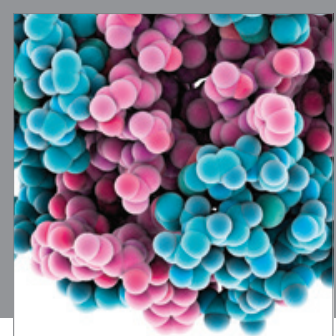

Journal of
Diabetes Research

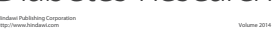

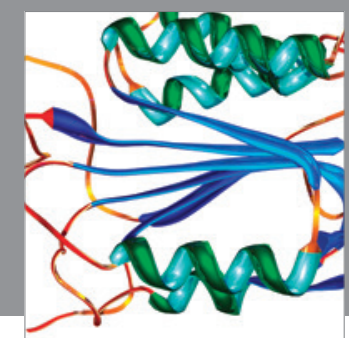

Disease Markers
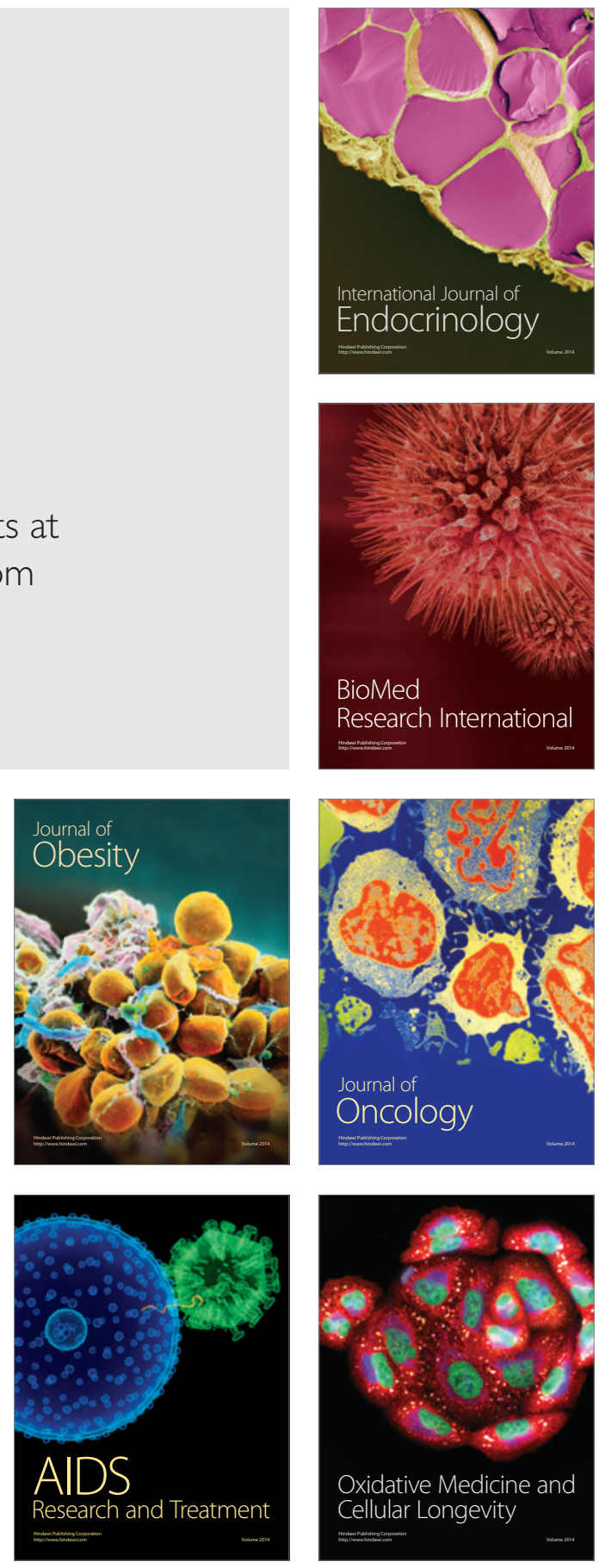